\title{
Renewable Energy Infrastructure. Importance to Reach Sustainability Goals. The Venezuelan Situation in 2016
}

\author{
Licia Pietrosemoli de Dikdan, $P h D^{1}$, Carlos Rodríguez-Monroy, $P h D^{2}$, \\ ${ }^{1}$ Universidad Politécnica de Madrid, Spain, lpietrosemoli@ costanorte.com.ve \\ ${ }^{2}$ Universidad Politécnica de Madrid, Spain, crmonroy@etsii.upm.es
}

\begin{abstract}
Renewable energy is fundamental for economic growth and sustainable development. To be generated, distributed and used renewable energy requires proper infrastructure. Venezuela is a country with important energy resources, mainly in hydropower, but despite the huge resources invested in the improvement of its infrastructure, the delays with projects' completion as well as the frequent blackouts show that there is a structural problem that hinders the attainment of the Energy for All Global Goals. This article presents an overview of the Venezuelan renewable energy potential, its importance to meet sustainability goals, some construction problems affecting this sector and the situation of renewable infrastructure in construction in the country. The conclusions highlight a complex problem whose solution requires deep changes in the Venezuelan energy policies and strategies.

Keywords-Renewable energy, sustainability, infrastructure, Venezuela.
\end{abstract}

Digital Object Identifier (DOI):

http://dx.doi.org/10.18687/LACCEI2016.1.1.072

ISBN: 978-0-9822896-9-3

ISSN: 2414-6390

$14^{\text {th }}$ LACCEI International Multi-Conference for Engineering, Education, and Technology: "Engineering Innovations for Global Sustainability", 20-22 July 2016, San José, Costa Rica. 


\title{
Renewable Energy Infrastructure. Importance to Reach Sustainability Goals. The Venezuelan Situation in 2016
}

\author{
Licia Pietrosemoli de Dikdan, $\mathrm{PhD}^{1}$, Carlos Rodríguez-Monroy, $\mathrm{PhD}^{2}$, \\ ${ }^{1}$ Universidad Politécnica de Madrid, Spain, lpietrosemoli@costanorte.com.ve \\ ${ }^{2}$ Universidad Politécnica de Madrid, Spain, crmonroy@etsii.upm.es
}

\begin{abstract}
Renewable energy is fundamental for economic growth and sustainable development. To be generated, distributed and used renewable energy requires proper infrastructure. Venezuela is a country with important energy resources, mainly in hydropower, but despite the huge resources invested in the improvement of its infrastructure, the delays with projects' completion as well as the frequent blackouts show that there is a structural problem that hinders the attainment of the Energy for All Global Goals. This article presents an overview of the Venezuelan renewable energy potential, its importance to meet sustainability goals, some construction problems affecting this sector and the situation of renewable infrastructure in construction in the country. The conclusions highlight a complex problem whose solution requires deep changes in the Venezuelan energy policies and strategies.
\end{abstract}

Keywords-Renewable energy, sustainability, infrastructure, Venezuela.

\section{INTRODUCTION}

The importance of renewable energy has been widely described by several authors. There is a growing awareness that this kind of energy, together with energy efficiency is fundamental to reach development goals, to reduce the impact of climate change and to create opportunities in a global and sustainable way. Renewable energy use has been growing faster in energy markets when compared with nonrenewable energy [1]. Renewable energy production and use is tightly linked to infrastructure progress. In fact, construction as infrastructure supplier has been described as one of the industries with highest impact on society's evolution [2] [3].

It is generally known that every country faces its own development challenges based on their national resources, strategies and public policies. From them different results may arise, being some more positive than others. Latin American countries have huge renewable energy potential mainly in hydropower [4] [5], and the region has made important investments to produce it, but according to the Renewable Energy Policy Network [1] world investments are still insufficient to reach the goal of Sustainable Energy for All.

Understanding the importance of learning from past experiences in order to make better decisions for the future, in the current research authors present a review of the importance of renewable energy and the Venezuelan potential in this area, the priority role of renewable energy infrastructure to reach sustainability goals as well as the main problems and current situation of the Venezuelan renewable energy infrastructure projects.

The conclusions highlight the difficult conditions that affect Venezuelan renewable energy infrastructure construction and maintenance with evidences of the necessity to establish important changes for the energy sector and in the whole socio economic Venezuelan framework in order to be able to take advantage from the huge resources and knowledge existing in the country, mainly in the hydropower sector.

This is suggested to sustain the path into Venezuelan productivity and competitiveness recovery as well as to address the country efforts to reach the Renewable Energy for All 2030 goals. In order to support such path some proposals for infrastructure construction and maintenance are presented aiming at the reinforcement of fundamentals of Venezuelan society.

\section{Renewable Energy. Venezuelan Potential}

Energy resources in Latin America are very important with a considerable diversity of energy options which range from gas to wind sources [6]. This shows the huge potential for energy development in this region.

In 2014, hydroelectric output worldwide accounted for a record of $6.8 \%$ of global primary energy consumption. Renewable energy sources continued to grow in 2014 in power generation and transport reaching a record of $3 \%$ of global energy consumption. In particular, Latin America has important hydropower development and in the last years the region has increased its demand for electricity [7].

Up to 2010, hydropower accounted more than 50\% of Latin America total electricity consumption [4]. This proves the importance of such renewable resources for the entire region.

Among the Latin American countries Venezuela is known because for its energy abundance. In fact, current oil and gas reserves make Venezuela one of the countries with the greatest hydrocarbon potential in the world. Furthermore to the fossil energy resources, Venezuela has been also known for being one of the main world producers of hydroelectricity, with exceptional geographical and hydrological conditions for the development of hydropower projects. In 2012 the country was ranked as the ninth world hydropower producer [8] [9]. 
With these resources available, the Venezuelan renewable energy sector is able to supply most of the country's energy needs and has an important potential for growth. In 2009 about $70 \%$ of the Venezuelan electricity needs were met by the large hydropower generation facilities built to use the water resources of the Caroní River.

The Venezuelan hydropower generation potential has important opportunities to be developed and used. Bautista [10] sustains that the country has all the conditions, including the technology needed to complete it path into sustainable development in the power generation sector.

This author also states that the quantity of thermal energy generated in Venezuela by natural gas and refined oil products increased in absolute terms by more than $27 \%$ and $36 \%$, respectively between 2006 and 2009. A similar behavior is explained by Al-mulali et al., [4] since those authors highlight an increase in electricity production from oil, gas and coal against the decrease in electricity production from hydroelectric sources.

This draws attention to the causes that may lie behind the reversion of the sustained trend of the growing use of hydroelectricity in Venezuela that was maintained until 1999.

\section{RENEWABLE ENERGY IMPORTANCE FOR SUSTAINABILITY.}

Energy has become one of the main issues in modern societies due to the fact that it is essential to sustain a country's development. Because of this the development of energy policies today is oriented by integral and comprehensive goals to guarantee security along with efficiency of supply, together with social and environmental sustainability [6].

This is why the gap in the access to modern energy services has been described as one of the limitations to achieve a sustainable socio-economic development. And by this means important efforts are dedicated all over the world to improve energy access to those who still do not have such services available or have them with limited quality [11].

Beyond its unquestionable environmental importance, the use of renewable energy is considered one of the basic strategies to sustain poverty reduction and sustainable development [5]. Additionally, renewable electricity consumption is acknowledged as a more fundamental element than nonrenewable to promote economic growth [4].

Regarding this fact, Apergis and Danuletiu [12] found a positive causality relation between renewable energy and economic growth in the long run.

Renewable energy has become a prevailing energy resource in many countries, both developed and developing, with important diffusion and use. This energy helps create new energy mixes that sustain countries' evolution [1].

Due to its capacity to offer solutions to fight poverty, the full access to energy has become an essential input for sustainable development with rising interest in the performance of this sector [13] [14] [15] and this emphasizes the strong relationship between energy and sustainability.

Oliver [16] sustains that from all renewable energy sources the main benefits are acknowledged to hydropower because of its abundance and availability and also for being supported by reliable and mature technologies and infrastructures. Thus hydropower is capable of supplying about $19 \%$ of the planet's electricity needs. In fact, accordingly to BP, in 2015 hydroelectric output accounted for the record of $6.8 \%$ of global primary energy consumption.

Notwithstanding the important efforts made in different countries to boost achievements in sustainability, severe inequalities still persist, with millions of people suffering the consequences of poverty [14] [17] [18] and this implies the need to improve the results of current sustainable strategies.

This reality means that additional efforts must be addressed to make progress with sustainability efforts and this is particularly important in Latin America, a region with evident disparities since, in spite of its huge energy resources, it still suffers from energy supply shortages and inefficiencies which affects millions of people living in slums [6], meaning that the region is still unable to generate all the energy needed to meet its population demands.

The development of energy policies and strategies is different from region to region. In Latin America energy plays a very important role because of the abundance of the natural resources available, mainly hydropower.

Experts state that there are insufficient studies to evaluate the full relationship between renewable and nonrenewable electricity consumption and economic growth in Latin America [4] as well as their potential to support sustainable development.

Nonetheless, available evidences clearly show the opportunities that renewable energy may bring to improve some countries' overall performance. This is the case of the current research regarding the Venezuelan situation based in renewable construction projects performance.

\section{INFRASTRUCTURE KEY ISSUE FOR SUSTAINABILITY GOALS.}

To be able to grow and evolve all nations need the support of suitable infrastructure, needed to supply from the basic protection and survival needs, including housing, food, water, education and health to the more sophisticated services of transport, industry, energy and telecommunications [18] [19] [20].

This is why it would be impossible to reach the Millennium Development goals without the investments required to provide the access to the modern and clean energy still needed for billions of people.

The availability of an adequate infrastructure for water, energy, roads, industry or communications has an important effect over national costs, logistics and processes in general, with a positive influence on population health and educational levels and to reduce income inequalities [18] [19].

$14^{\text {th }}$ LACCEI International Multi-Conference for Engineering, Education, and Technology: "Engineering Innovations for Global Sustainability”, 20-22 July 2016, San José, Costa Rica. 
These facts sustain the important correlation existing among infrastructure availability and quality and country productivity and competitiveness and show why infrastructure is considered the second pillar with which countries can sustain their competitiveness efforts [20].

This is particularly important in Latin America since the poor quality and shortage of infrastructure available are described as severe limitations for regional competitiveness and sustainable development [20] [21] [22], so the construction and maintenance of large power generation and distribution infrastructure become a key factor to improve quality of life and to support sustainable development.

Moreover, Latin American needs renewable energy infrastructure in order to meet the UN's Sustainable Energy For All initiative. This is imperative to be able to offer universal access to energy by 2030 as a key target and thus to support the improvement of living conditions for millions of people [11].

But beyond recognizing this priority it is important to understand the different limitations that make it harder to reach the renewable infrastructure needed to support sustainable development. Such limitations arise from each different national reality.

In fact, both energy and construction policies and activities are conditioned by energy sources, resources availability, environmental constraints, energy consumption growth and in general by the social and political context [6].

This is why among other important issues needed to have adequate infrastructures we find the capacity to attract investments, which in Latin America is not easy for all countries.

In other cases political instability is a factor that weakens public energy policy development [6].

Having such constraints as reference, in general there is no doubt that renewable energy is essential to offer sustainable solutions for society, and this demonstrates the importance of proper evolution of the infrastructure projects related to energy production, distribution and use as they are fundamental to improve quality of life and to support sustainable development [5].

The construction and maintenance of renewable energy facilities is very complex because it requires massive investments and multifaceted knowledge.

Additionally, it requires the balanced coordination of technical, socio-economic, environmental and political conditions and interests groups to make it possible to respond appropriately to the requirements related to this kind of projects.

This is an important challenge for all the countries, and in particular for developing ones. And this is why the sustainable construction guidelines become a fundamental issue to sustain the efforts needed to accomplish the renewable energy projects planned [5].

According to the Renewable Energy Policy Network for the 21st Century [1] in 2014 renewable energy expanded in terms of installed capacity as well as in energy produced, with important investments that exceeded those made in the field of non-renewable energy.

Al-Mulali et al, [4] indicate that in the Latin American countries the investments in power generation increased in the 1980-2010 period in different proportions among countries but the funds allocated to such projects were still insufficient to achieve the Sustainable Energy for All goal .

\section{CONSTRUCTION PROBLEMS}

The infrastructure evolution depends on construction progress. But construction projects in general are not easy to implement since each structure is unique and in order to be executed the compliance with strict technical regulations as well as legal and quality control standards are required, all in perfect balance with the utilization of local resources. The respect to environmental guidelines and to owners' and communities' demands is also a priority. All these requirements need to be met in order to have sustainable construction projects.

But besides those expected conditions, the development of construction projects is frequently influenced by diverse factors which may prevent the realization of the planned constructive goals.

Such factors are related with technical, legal, financial, labor or social issues that frequently hamper projects and create diverse risks that may create changes in contract conditions. This may lead to diverse consequences and problems.

The construction problems arise from various causes. In some cases there are mistakes with technical specifications or facilities design, or constructors rely on wrong construction techniques. In other cases builders follow poor management procedures, have knowledge management problems, their quality control processes fail or are unable to establish good cooperation with the members of the supply chain. [3] [23].

In other cases the changes may arise from unexpected circumstances related to financial resources limitations or materials and equipment unavailability, or even by environmental conditions caused by extreme weather or natural disasters. Social factors such as labor unrest or social demands and claims can create important alterations in original construction programs also.

Fulford and Standing [24] highlight the severe influence of such conditions in general construction processes e.g. design, materials requests, planning, product delivery, personnel or subcontractors management and their negative influence on project productivity.

In general, the combination of such diverse factors create important gaps among the project the way it was conceived and the project is being built and this determines that infrastructure projects in general are associated with high risks [25]. 
Diverse authors agree that the most frequent construction problems present in different geographic locations are the ones described in Table I.

TABLE I

Main Problems AfFecting Construction PeRformanCE Financial

Client not paying on time + High costs, inflation

Lack of capital/ credit facilities -Dificulties to arrange guarantees

Excess of costs over budget-Dificulties to recover over-costs with clients Technical conditions

Technical/ specification/ contractual shortages + Change orders

Jobsite conditions/ Interferences

Project extention of time

Quality deviations/ Quality control problems

Physical Resources

Material and equipment unavailability and costs superior to budgets

Material and equipment losses - General resources waste

Reduced productivity levels- Time lost

General conditions

Poor quality of general performance

Change in government regulations/ Economic-Political instability/ Adverse weather

Low investment on urban \& or construction sustainability Intangible resources/Knowledge Management

Limited comprehension \& Interest about construction problems \& Sustainable construction

Planning, design \& project control problems

Leadership \& accountability shortage. Resistance to change

Gaps of knowledge, knowledge management constraints and poor coordination among members of the supply chain

Underutilization of lessons learned \& intangible assets

Source: Authors' summary from [21] [23] [25] [26] [27] [28] [29] [30] [31] [32] [34] [35] [36]

The combination of such diverse conditions generates delays, costs overruns, labor unproductivity and unrest. Moreover such conditions frequently cause high levels of waste and lost resources, conflicts between ownership and constructors and social distress.

This also may lead to resources lost and unfinished projects and establish limitations for the country to be competitive and grow.

This is why all such complications jointly cause severe consequences to society in general with negative effect in the performance of important infrastructure projects. Such problems are present in diverse developed and developing countries including Venezuela as it will be described in the following sections.

\section{Some Problems Affecting the RenewABle ENERgy PROJECTS IN VENEZUELA. SitUATION IN 2016.}

The problems described in previous section are very well known for Venezuelan constructors. Nonetheless, to evaluate the particular case of renewable energy projects in Venezuela is a complex matter considering the limited availability of solid and accurate data and official statistics.
This is an important constraint since the country is characterized by structural gaps and limitations in statistics and indicators [37] [38] [39].

Confirming such limitations Fay and Morrison [21] point out that in general Latin America suffers problems of insufficient data about infrastructure. This establishes important constraints to researchers.

Regarding the Venezuelan case, there are no official statistics about the performance of public investments in infrastructure.

The Universities, Industry, Commerce, Construction or Oil Chambers, that in general cluster the main companies related to the infrastructure supply chain (Consultants, manufacturers, goods and services suppliers and constructors), have very limited access to statistics to evaluate the goals, budgets, advancements, problems, or lessons learned of undergoing or completed Venezuelan infrastructure projects.

Because of these restrictions researchers must investigate from other data sources and use international indicators when available.

Since 2007 the state owned Corporación Eléctrica Nacional (CORPOELEC) is the responsible institution for the control of the entire Venezuelan electric sector, from generation to commercialization, including the development of electricity public policies and sectoral statistics [10]. Unfortunately the information available from this organization is not updated in areas as infrastructure availability and projects progress.

Accordingly to US Energy Information Administration (EIA) [40] between 2003 and 2012, Venezuela's electricity consumption grew by $49 \%$ while installed capacity had only a $28 \%$ increase, showing the impossibility to meet the country's growing demand.

Historically about $60 \%$ of the Venezuelan demand has been supplied by hydroelectricity with energy supplied from the 10,200 megawatt Guri hydroelectric power plant located in the Southern Guayana region in the Caroni River Basin and other hydroelectric facilities around.

Guri power plant is one of the largest hydroelectric dams in the world and provides most of Venezuela's electric power.

Al-mulali [4] states that Venezuela increased its percentage of electricity production from hydroelectric sources in a sustained trend up to 1999 when this path reversed and energy produced from oil, gas and coal increased. Bautista [10] also indicates that even if the Venezuelan power sector is driven by hydrosources, the share of hydropower has been decreasing in Venezuela in the last years with an increase of energy generated from natural gas and gasoil.

CORPOELEC [41] indicates that in recent years Venezuela has been investing many resources in the power sector infrastructure in order to increase the generation and transmission capacity to supply the energy needed to meet demand.

$14^{\text {th }}$ LACCEI International Multi-Conference for Engineering, Education, and Technology: "Engineering Innovations for 
In fact, for the 2008-2014 period the Venezuelan government informed about the plans to increase the electricity supply with 10,420 MW of additional generation.

Such increase should arrive from the construction of new plants or the refurbishment of facilities located all around the country e.g. hydroelectric plants Simón Bolívar (Guri), Antonio José de Sucre (Macagua I), Manuel Piar (Tocoma), Fabricio Ojeda (La Vueltosa) or thermoelectric plants such as Ezequiel Zamora, Alberto Lovera, Juan Manuel Valdez (CIGMA), Termozulia or Josefa Camejo, among other [41].

Bautista [10] states that from the 2010-2015 period CORPOELEC planned to build a total of 9,915.40 MW, of which $65.64 \%$ were thermal power plants $(6,509 \mathrm{MW})$ and 26,97\% (2,694MW) were hydropower plants.

Notwithstanding this investment plans, in Venezuela there are special infrastructure and institutional conditions that become limitations to take advantage of existing resources and limit the achievement of the goals established with such projects. This implies that the country has several opportunities to improve and take better advantage of its energy potential [10].

In fact Portillo [42] sustains that the important efforts and investments oriented to improve the Venezuelan energy infrastructure have been limited because the construction sector in general grieves from the effect of severe legal and financial constraints.

Such constraints in general are related to the preeminence of political over technical decisions, frequent strikes and conflicts at worksites, inflation, foreign currency restrictions, restrictive labour regulations, technical, labour, knowledge or material limitations, social violence, inflation and inefficient bureaucracy that make it harder to complete the projects.

In line with this assessment the World Economic Forum indicates that Venezuela is ranked in the 132nd position out of 140 countries in the Global Competitiveness Index (GCI) for 2015-2016 period. Only ten years before, in 2005-2006 Venezuela occupied the $84^{\text {th }}$ position [20].

Some reasons behind such competitiveness deterioration are explained by the worsening of basic requirements (e.g. institutions, infrastructure and macroeconomic environment); efficiency enhancers (e.g. higher education and training, goods and labour market efficiency) or innovation and sophistication factors (e.g. innovation).

This context, together with the most problematic factors for doing business, that include foreign currency regulations, inflation, inefficient government bureaucracy, restrictive labour regulations, policy instability, corruption and crime [20] describe the prevailing rough conditions to develop infrastructure projects in Venezuela.

Acknowledging the existence of serious problems for this sector, CORPOELEC [41] described that some difficulties affecting the projects in progress were caused by insufficient labour productivity and unrest, conflicts created by local communities, purchases and imports of machinery, materials and equipment, as well as legal, contractual, financial and construction delays.

In other occasions energy shortages and energy infrastructure construction delays are attributed by Venezuelan authorities to sabotage or climate conditions.

In 2015 EIA [40] confirmed that in diverse moments Venezuela has implemented electric power rolling blackouts, to reduce industrial production and in general to restrict energy consumption.

Currently there is limited official information available related to the status of the projects scheduled by CORPOELEC as well as the real conditions of all the electric system.

Since available data is scarce there is no confirmation of how much of the planned investments were performed in the indicated period.

Based in the information available in CORPOELEC web pages authors prepared a summary of infrastructure projects in execution to 2016.

A comparison of information available for the same projects in 2012 was included in this summary.

Table II presents a summary of the infrastructure electric generation projects from hydroelectricity sources that appear to be in construction or refurbishment in 2016.

TABLE II

VENEZUELAN MAIN ELECTRIC GENERATION PROJECTS IN 2016HYDROELECTRICITY

\begin{tabular}{|c|c|c|c|c|c|}
\hline $\begin{array}{c}\text { Plant/Project } \\
\text { type }\end{array}$ & $\begin{array}{c}\text { Capacity } \\
\text { MW }\end{array}$ & $\begin{array}{l}\text { Project } \\
\text { Beginnin } \\
\mathrm{g}\end{array}$ & $\begin{array}{l}\text { Scheduled } \\
\text { start-up }\end{array}$ & $\begin{array}{c}\text { \% of } \\
\text { completion } \\
\text { in Nov. } \\
2012 \\
\end{array}$ & $\begin{array}{c}\text { \% of } \\
\text { completion } \\
\text { in Jan. } \\
2016 \\
\end{array}$ \\
\hline $\begin{array}{l}\text { Simón Bolívar } \\
\text { (GURI)/R }\end{array}$ & 700 & 2001 & 2014 & $35 \%$ & $35 \%$ \\
\hline $\begin{array}{l}\text { Manuel Piar } \\
\text { (TOCOMA)/C }\end{array}$ & 2160 & 2002 & $\begin{array}{l}2012 \\
2014\end{array}$ & $66 \%$ & $66 \%$ \\
\hline $\begin{array}{l}\text { Fabricio } \\
\text { Ojeda (La } \\
\text { Vueltosa)/C }\end{array}$ & 514 & 2004 & 2010 & $72 \%$ & $72 \%$ \\
\hline $\begin{array}{l}\text { Antonio J. de } \\
\text { Sucre } \\
\text { (Macagua I)/R }\end{array}$ & 120 & 2006 & 2014 & $44 \%$ & $44 \%$ \\
\hline Masparro/C & 25 & 2005 & 2009 & N/A & $100 \%$ \\
\hline
\end{tabular}

Table III presents a summary of the infrastructure electric generation projects from thermoelectricity sources that appear to be in construction or refurbishment in 2016. 
TABLE III

VENEZUELAN MAIN ELECTRIC GENERATION PROJECTS IN 2016THERMOELECTRICITY

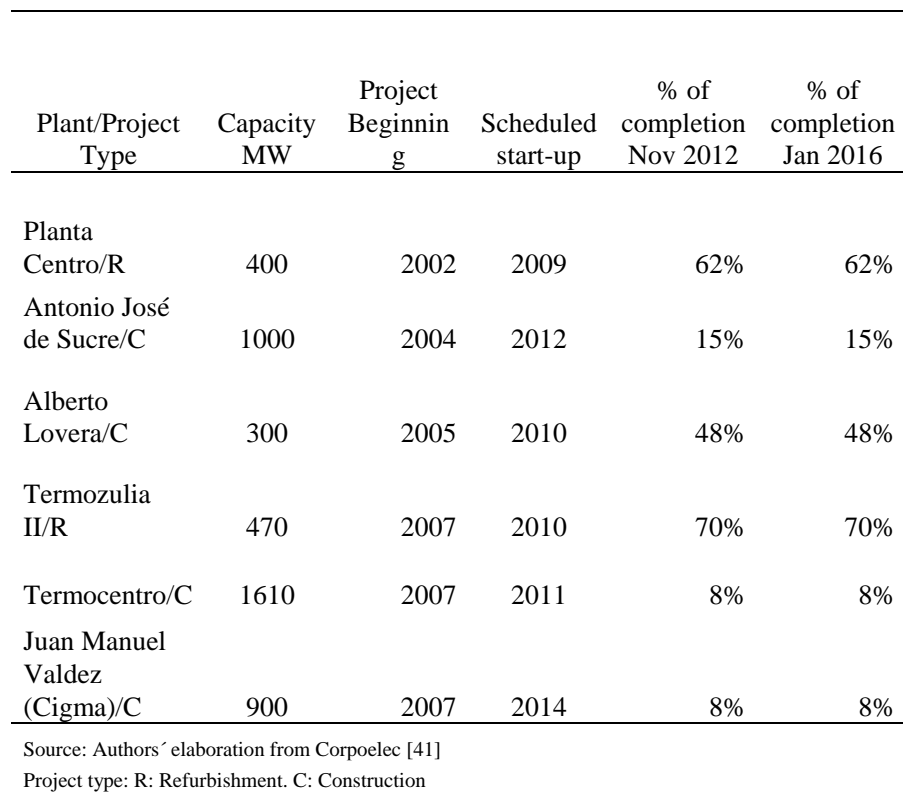

The Corpoelec webpage does not include further information regarding such projects, so it was impossible for authors to validate their current situation, especially since there are no reports from projects evolution from 2012 to 2016.

Although available data is not enough to conclude what really happens with the development of renewable and nonrenewable energy projects in Venezuela the current set of completion and the noncompliance with scheduled start-ups shown in the previous tables, evidence that there are important problems in this sector. This is palpable since most of the projects started more than 10 years ago and their planned startup has been delayed for years.

At present there is no information about startup reprogramming.

Along with that, the information present in newspapers, the frequent energy shortages, the popular claims, road blockages and protest evidence the discomfort that affect the Venezuelan population.

VII. Sustainable Construction Proposals tO IMPROVE VENEZUELAN RENEWABLE ENERGY INFRASTRUCTURE. CONCLUSIONS.

The renewable energy infrastructure as a means to reach the sustainability goals established needs no further explanation.

In fact there is a general acknowledgement about its key importance for sustainability.

This is evident looking at the efforts dedicated and progress achieved by many countries and by international organizations which invest in the construction or refurbishment of the infrastructure needed to make available renewable energy for all as primary goal.

Additionally to this conclusion, that confirms a positive trend in global markets, the article suggests that there are some cases in which the efforts to expand renewable energy seems that they are not addressed in the proper way.

The complex situation described with energy infrastructure in Venezuela - that despite large investments made during several years show insufficient progress with the completion of the renewable and nonrenewable facilities - is just an example of deeper problems in Venezuelan socioeconomic framework.

In direct terms this failure to meet energy goals generates social dissatisfactions and conflicts, loss of competitiveness, delays or even reversion in the socio-economic growth.

This led to a serious deterioration in the living conditions of society, and includes severe damages to production capacity. The situation creates a vicious circle that may become very dangerous for the Venezuelan future.

To solve such problems valuable technical and economic proposals has been suggested by Venezuelan and international experts during the past years.

Recently general reforms were proposed by the new National Assembly in areas as complete as legal and political framework, food, oil, energy production, industry and construction, safety, educational, medical and environmental issues, all oriented to recover institutions, productivity and competitiveness. There is an important expectation from Venezuelan society that such proposals are included in government plans to improve this sector performance.

Regarding the Venezuelan construction sector it is imperative to establish important changes to be able to develop the energy, and in general all national infrastructure.

Some ideas that may support the achievement of this goal are the following:

1. The country must acknowledge the existence of a structural problem that impedes the completion of the undergoing projects.

2. The basic principles of sustainable construction - still absent in Venezuelan official discourse - must be included in all the construction programs.

3. The construction actors, including government, research centers, professional associations and companies must evaluate the problems existing behind the delays with projects described in tables II and III and in other infrastructure plans.

4. Such lessons learnt must be considered to identify the causes of problems and projects performance in order to establish the proper strategies that may help to reduce the causes of delays and improve construction performance.

5. Public policies, labor laws, currency control, insecurity factors, energy limitations must be

$14^{\text {th }}$ LACCEI International Multi-Conference for Engineering, Education, and Technology: "Engineering Innovations for 
evaluated in deep to eliminate the factors that constrain competitive efforts.

6. The facilities described in tables II and III must be built and delivered accordingly with specifications following the sustainable construction guidelines. This is mandatory to be able to meet the Venezuelan growing energy demand with a long term approach.

Additionally to such basic proposals, that are fundamental to address the energy infrastructure in a positive way, the country in general must evaluate the conditions that limit its competitive strategies in order to concentrate all the efforts and be able to improve national performance.

It is important to understand that to be successful all the legal and technical proposals presented by experts must be supported by some fundamental intangibles.

To be able to implement such practical strategies and reforms and correct the Venezuelan risky path of insecurity, production disruptions, energy scarcity and loss of productivity and competitiveness deeper changes are required.

Besides the practical solutions it is also needed that the Venezuelan government and authorities, together with universities and research centers, private companies and chambers as well as citizens, pursue the basic fundamental principles that sustain successful societies.

This means looking at the country with a long term approach, socio-economic balance, the understanding of work and education as a mean of progress, the necessity of ethics, controls, rational use of resources, knowledge management and sustainability as fundamental elements to recover a sustainable path.

Only if technical strategies are accompanied by efforts to reinforce structure of Venezuelan framework the renewable energy infrastructure projects will be performed according to the construction plans.

Having a solid framework of technical, legal and financial conditions and knowledge, based on true data and indicators the deviations that may appear - caused by unexpected changes in contract conditions - will be reoriented with the sustainable construction criteria in order to enable to perform and complete the project planned.

Based in such new approaches the investments made in infrastructure will allow the increase of energy supply in Venezuela and in this way the country will support the Energy For All goal.

\section{REFERENCES}

[1] Renewable Energy Policy Network for the $21^{\text {st }}$ century. "Renewables 2015. Global Status Report”. Ren21. 2015

[2] G. Winch, Managing Construction Projects. Wiley-Blackwell, 2010

[3] L. Pietrosemoli, Doctoral Thesis "Modelo de gestión del conocimiento para la competitividad del Sector de las Construcciones Petroleras, Petroquímicas y Energéticas Venezolanas”. Universidad Politécnica de Madrid. 2014

[4] U. Al-mulali, H. Fereidouni, J. Lee, "Electricity consumption from renewable and non-renewable sources and economic growth: Evidence from LatinAmerican countries”. Renewable and Sustainable Energy Reviews, 30, 290-298. 2014.

[5] L. Pietrosemoli and C. Rodríguez-Monroy, "The impact of sustainable construction and knowledge management on sustainability goals. A review of the Venezuelan renewable energy sector". Renewable and Sustainable Energy Reviews. 27 (2013) 683-691(2013).

[6] S. Mocarquer, et al, "Balance of power". IEEE Power and Energy Magazine. Sept/Oct 2009.

[7] BP Statistical Review of World Energy 2015.

[8] BP Statistical review of World Energy 2012.

[9] Revista de obras públicas. Presa y Central de Caruachi. "Un emblemático proyecto hidroeléctrico en Venezuela”. N. 3416. 39-56. December 2001

[10]S. Bautista, "A sustainable scenario for Venezuelan power generation sector in 2050 and its costs”. Energy Policy 44 (2012) 331-340.

[11]F. Fuso Nerini, et al, "A cost comparison of technology approaches for improving access to electricity services". Energy 2016 255-265 http://dx.doi.org/10.1016/j.energy.2015.11.068

[12]N. Apergis \& D. Danuletiu. "Renewable Energy and Economic Growth: Evidence from the Sign of Panel Long-Run" International Journal of Energy Economics and Policy Vol. 4, No. 4, 2014, pp.578-587 ISSN: 2146-4553

[13]M. Zilio, M. Recalde "GDP and environment pressure: The role of energy in Latin America and the Caribbean”. Energy Policy. Vol 39, Issue 12. 7941-7949. 2011.

[14]A. Bhide and C. Rodríguez-Monroy, "Energy poverty: A special focus on energy poverty in India and renewable energy technologies”. Renewable and Sustainable Energy Reviews 15 1057-1066. (2011)

[15]R. Kothari, V., Tyagi A. Pathak. "Waste-to-energy: A way from renewable energy sources to sustainable development". Renewable and Sustainable Energy Reviews 14 3164-3170. (2010)

[16]P. Oliver, "Small hydropower: Technology and current status". Renewable and Sustainable Energy review 6 (2002) 537-556(2002)

[17]S. Chen, M. Ravallion, "The Developing World is Poorer Than We Thought But Not Less Successful in the Fight against Poverty”. The World Bank Development Research Group. 2009. Policy Research Working Paper 4703.

[18]CIB \& UNEP-IETC. “Agenda 21 for Sustainable Construction in Developing Countries”. Boutek Report Bou/ E0204. 2002.

[19]M. Fay, T. Yepes. "Investing in infrastructure: What is needed from 2000 to 2010? "World Bank Policy Research Working Paper 3102, July 2003.

[20]World Economic Forum. 2015. The Global Competitiveness report 201516

[21]M. Fay and M. Morrison, "Infrastructure in Latin America and the Caribbean. Recent development and key challenges. The World Bank. 2007

[22]OCDE 2013, "Perspectivas económicas de América Latina 2014. Logística y competitividad para el desarrollo"

[23]S. Assaf, S. Al-Heijji, "Causes of delay in large construction projects." International Journal of project management. Vol. 24. May 2006. Pp. 349. (2006). ANTES 23

[24]Fulford Richard y Standing, Craig, (2014). Construction industry productivity and the potential for collaborative practice. International Journal of Project Management. 32 (2014) 315-326.

[25]Doh J., Ramamurti R., (2003). Reassessing Risk in Developing Country Infrastructure. Long Range Planning 36 (2003) 337-353.

[26]Gomes, V., Gomes Da Silva, M., (2005). Exploring Sustainable Construction: Implications from Latin America. Building Research and Information. Volume 33, number 5, Septiembre-Octubre 2005. Pp. 428440 (13)

[27]Abdul-Rahman H, Berawi M; Berawi A; Mohamed O, Othman M, Yahya I., (2006). Delay Mitigation in the Malaysian Construction Industry. Journal of Construction Engineering and Management. ASCE. Febrero. Pp. 125-133.

[28]Ortiz, O.; Castells, F. y Sonnemann, G., (2009). Sustainability in the construction industry: A review of recent developments based on LCA. Construction and Building Materials 23. 28-39.

[29]Flyvbjerg, B.; Garbuio, M. y Lovallo D., (2009). Delusion and deception in large infrastructure projects. Two models for explaining and preventing

$14^{\text {th }}$ LACCEI International Multi-Conference for Engineering, Education, and Technology: "Engineering Innovations for 
executive disasters. Californian Management Review. 51, Issue 2. 170194.

[30]Kamara J., Anumba C. y Carrillo P., (2002). A CLEVER approach to selecting knowledge management strategy. International Journal of Project Management. Vol. 20, Issue 3, Abril. 205-211.

[31]Egbu C.; Hayles C.; Quintas P.; Hutchinson V.; Anumba C.y Ruikar K., (2004). Knowledge management for Sustainable Construction Competitiveness. Final report. Julio. BNE Report 23/2004. http://www.knowledgemanagement.uk.net/. Revisado Marzo de 2014.

[32]Anumba, Chimay, Egbu, Charles y Carrillo Patricia, (2005) Knowledge management in construction. Blackwell Publishing Ltd. India. Pp. 226.

[33]Love, Peter; Fong, Patrick e Irani, Zahir, (2005). Management of knowledge in project environments. Elsevier Butterworth Heinemann. USA. Pp. 242.

[34]Tan H.; Anumba C.; Carrillo P.; Bouchlaghem D.; Kamara J. y Udeaja C., (2010). Capture and reuse of project knowledge in construction. WileyBlackwell. Pp. 195.

[35]Khalfan M.; Maqsood T; Egbu C., Ali Noor, M., (2011). Supply chain capital in construction industry: a conceptual model, In proceedings of the CIB W78 W-102 Computer Knowledge Building. Francia.

[36]Díez Pérez, José Ignacio; Sáiz Bárcena, Lourdes; Manzanedo del Campo, Miguel Ángel y Rodríguez Monroy, Carlos, (2014). Estudio TeóricoEmpírico de las Barreras al Intercambio del Conocimiento en la Empresa. Interciencia. Vol. 39. N. 3. Marzo. 156-163

[37]L. Sequera, "Impacto de las TIC en la aplicación de políticas públicas caso Venezuela”. XII Congreso de estudiantes y graduados de ciencias políticas UCV. 2002. Revista UCV124 409-428. 2002

[38]I. de la Vega. Cienciometría y política científica en la periferia: el caso Venezuela. Revista Espacios Vol. 24 (1) 2003.

[39]International crisis group 2015. VENEZUELA. Un desastre evitable. Informe breve sobre America Latina. N. 33 Caracas-Bogota-Bruselas. 30 Jul 2015

[40]EIA Country Analisys in brief: Venezuela. Nov 252015.

[41]Corpoelec. 2012 http://www.corpoelec.gob.ve. Revised September 2012ANTES 28

[42]C. Portillo. "Crisis eléctrica en Venezuela. Dónde estamos y hacia dónde vamos”, Foro Energía y Petróleo. 2011. Universidad del Zulia. Venezuela

14 ${ }^{\text {th }}$ LACCEI International Multi-Conference for Engineering, Education, and Technology: "Engineering Innovations for Global Sustainability”, 20-22 July 2016, San José, Costa Rica. 